\title{
FAKTOR-FAKTOR YANG MEMPENGARUHI KEPATUHAN WAJIB PAJAK DALAM MEMBAYAR PBB DENGAN VARIABEL MODERATING SIKAP WAJIB PAJAK ATAS SANKSI DENDA. (Studi Empiris Pada Wajib Pajak Orang Pribadi Dikota Tidore Kepulauan)
}

\author{
HASANNUDIN \\ (email: hasannudin2h@gmail.com)
}

\begin{abstract}
Taxation is a source of enormous revenue contribution in the financing needs of government spending and national development. UN entry of urban and rural areas in 2010 as a local tax, assessed will contribute significantly to the increase in revenue (PAD). Tidore Tidore island is one of the autonomous regions that have natural resources and a limited area, so that the UN considered to be very potent in increasing revenue Tidore islands, because it has an advantage in this regard, is the object of the UN, the land and buildings that are clear designation compared with other tax potential. Data obtained from DISPENDA Tidore islands associated with the acceptance of the United Nations rural and urban, showed that there is still a sizeable UN arrears of revenue realization of the United Nations, especially in 2012 that showed a significant difference between actual revenue in the amount of 77,878,186 principal. and arrears amounting to 568826 671. it indicates that there are a number of factors that influence taxpayer compliance in paying UN Tidore islands in the city. The purpose of this study was to determine the factors that influence taxpayer compliance in paying UN moderated attitude taxpayer on the implementation of financial penalties. The method used in this study was a multiple linear regression. Research results showed that awareness of the taxpayer, the taxpayer's motivation, and economic level of each taxpayer partially no effect on taxpayer compliance in paying the UN, and each of which is moderated by the attitude of the taxpayer on the implementation of financial penalties. Where the taxpayer stance on the implementation of financial penalties is not a moderating variable, melaikan independent variables. While the partial attitude of the taxpayer on the implementation of fines effect on taxpayer compliance in paying the UN. it shows that the revenue department Tidore islands has a poor performance and not optimal in managing urban and rural United Nations.
\end{abstract}

Keywords: land and building tax, taxpayer Awareness, Motivation taxpayer, Level Economic Taxpayer, Taxpayer Compliance Taxpayer Attitude On the performance of Sanctions Fines.

\section{PENDAHULUAN}

\section{Latar Belakang}

Pajak merupakan sumber penerimaan negara yang sangat besar kontribusinya dalam membiayai kebutuhan belanja negara dan pembangunan nasional. Untuk mengefektifkan penerimaan pajak maka Pemerintah melalui Kantor Pelayanan Pajak selalu berupaya memberikan sosialisasi kepada wajib pajak melalui iklan di media cetak maupun elektronik akan pentingnya penerimaan pajak bagi keberlangsungan pembangunan bangsa. Selain sosialisasi, undang-undang no 28 tahun 2007 tentang ketentuan umum dan tata cara perpajakan (KUP) mengatur mengenai sanksi berupa denda, penyitaan, penyegelan maupun penahanan bagi wajib pajak yang dengan sengaja mengabaikan atau melanggar kewajiban perpajakannya. Dengan demikian maka hal tersebut diharapkan dapat meningkatkan penerimaan pajak dan mengurangi adanya ketidakpatuhan pajak.

Otonomi Daerah yang terjadi pada tahun 1999 membawa dampak terhadap pembagian wewenang pengumutan pajak, yaitu pajak yang dipungut oleh pemerintah pusat atau yang disebut dengan pajak pusat dan pajak yang dipungut oleh pemerintah daerah atau yang disebut dengan pajak daerah, yang semula hanya dipungut oleh pemerintah pusat. Pajak pusat terdiri dari, Pajak Pajak Pertambahan Nilai (PPn), Pajak Penjualan Barang mewah (PPnBm), Pajak Penghasilan (PPh) Pajak Migas, PBB atas Perkebunan, Kehutanan, dan lain sebagainya. Sementara Pajak Daerah terbagi atas Pajak Provinsi yang terdiri atas : pajak kendaraan bermotor, bea balik nama atas kendraan bermotor, pajak bahan bakar atas kendaraan bermotor, pajak air permukaan, dan pajak rokok. Dan Pajak Kabupaten/Kota yang terdiri atas : pajak hotel, pajak hiburan, pajak restoran, pajak reklame, pajak parkir, pajak mineral bukan logam dan lainnya, dan yang terakhir dengan masuknya pajak bumi dan bangunan (PBB) pedesaan dan perkotaan pada tahun 2010.

Dalam praktek pengumutan pajak sering dijumpai adanya tindakan perlawanan/penghidaran pajak (Tax Avoidance), baik yang dilakukan secara aktif maupun pasif. Dengan kata lain kedua tindakan tersebut dilakukan secara sengaja oleh wajib pajak maupun secara tidak sengaja karena dipengaruhi oleh struktur ekonomi wajib pajak, perkembangan moral dan intelektual penduduk, dan teknik pemungutan pajak itu sendiri. Contoh kasus perlawanan pajak secara aktif adalah kasus pajak yang menimpa gayus tambunan, sementara kasus perlawanan 
pajak secara pasif, salah satunya adalah kasus penghindaraan pajak bumi dan bangunan pedesaan dan perkotaan (PBB P2) yang umumnya dilakukan karena ketidakseimbangan antara kepemilikan tanah dan bangunan yang dimiliki wajib pajak, yang merupakan hasil dari warisan dan kemampuan ekonomi wajib untuk melaksanakan kewajiban perpajakan tersebut.

kasus penghindaran pajak secara aktif dan pasif yang telah dijelaskan sebelumnya mengindikasikan adanya faktor-faktor perilaku wajib pajak yang mempengaruhi kepatuhan wajib pajak, baik yang dipengaruhi oleh rendahnya kesadaran wajib pajak, tingkat ekonomi wajib pajak maupun sejumlah faktor-faktor lainnya. Dalam teori atribusi dijelaskan bahwa perilaku seseorang dalam hal ini karakter, sikap dan lainnya dipengaruhi oleh keadaan eksternal seperti tekanan situasi atau keadaan yang memaksa seseorang untuk melakukan tindakan tertentu (dikutip dari Jatmiko, 2006).

Berdasarkan pada sejumlah kasus pajak dan teori atribusi yang telah dijelaskan sebelumnya maka peneliti tertarik untuk melakukan penelitian tentang faktor-faktor yang mempengaruhi kepatuhan pembayaran PBB di Kota Tidore Kepulauan. Hal tersebut dilatarbelakangi oleh dua alasan. Pertama, berdasarkan data penerimaan pajak yang peneliti peroleh Dinas pendapatan daerah kota tidore kepulauan menunjukan bahwa selama kurun waktu dari tahun 2010-2013 tercatat terjadi penurunan yang signifikan terhadap penerimaan pokok PBB P2, salah satunya yang terbesar terjadi pada tahun 2012 yaitu dengan selisih penerimaan pokok sebesar 77.280.864 dan tunggakan sebesar 568.826.671 dari total pajak terhutang sebesar 646.704.857.

Kedua, PBB P2 merupakan pajak yang potensial di Kota Tidore Kepulauan dibandingkan potensi pajak lainnya, mengingat Kota Tidore adalah daerah berkembang yang masih minim infrastruktur dan pengelolaan sumber daya alamnya belum dikelola secara maksimal, selain itu PBB P2 yang sudah jelas dari segi tarif, objek maupun subjeknya, sehingga tergantung dari sejauh mana pemerintah daerah melalui dinas pendapatan daerah mengoptimalkan potensi tersebut guna untuk meningkatkan pendapatan asli daerahnya.

Dari beberapa argumentasi diatas maka penelitian ini berjudul : faktor-faktor yang mempengaruhi kepatuhan dalam pembayaran PBB yang dimoderasi oleh sikap wajib pajak atas sanksi denda (studi kasus di kota tidore kepulauan).

\section{Tujuan Penelitian}

1. Untuk menganalisis pengaruh kesadaran wajib pajak terhadap kepatuhan wajib pajak dalam membayar pajak bumi dan bangunan (PBB).

2. Untuk menganalisis peran sikap wajib pajak atas pelaksanaan sanksi denda dalam memperkuat pengaruh kesadaran wajib pajak terhadap kepatuhan wajib pajak dalam membayar pajak bumi dan bangunan (PBB).

3. Untuk menganalisis pengaruh motivasi wajib pajak terhadap kepatuhan wajib pajak dalam membayar pajak bumi dan bangunan (PBB).

4. Untuk menganalisis peran sikap wajib pajak atas sanksi denda dalam memperkuat pengaruh motivasi wajib pajak terhadap kepatuhan wajib pajak dalam membayar pajak bumi dan bangunan (PBB).

5. Untuk menganalisi pengaruh tingkat ekonomi wajib pajak terhadap kepatuhan wajib pajak dalam membayar pajak bumi dan bangunan (PBB).

6. Untuk menganalisis peran sikap wajib pajak atas sanksi denda dalam memperkuat pengaruh tingkat ekonomi wajib pajak terhadap kepatuhan wajib pajak dalam membayar pajak bumi dan bangunan (PBB).

7. Untuk menganalisis pengaruh sikap wajib pajak atas sanksi denda terhadap kepatuhan wajib pajak dalam membayar Pajak Bumi dan Bangunan (PBB).

\section{TINJAUAN PUSTAKA \\ Penelitian Terdahulu}

Penelitan yang dilakukan oleh Jatmiko (2006) tentang pengaruh sikap wajib pajak terhadap sangsi denda, pelayanan fiskus dan kesadaran perpajakan atas kepatuhan wajib pajak. Hasil penelitiannya menunjukan bahwa masing-masing secara parsial sikap wajib pajak atas sanksi denda, pelayanan fiskus, dan kesadaran wajib pajak berpengaruh positif signifikan terhadap kepatuhan wajib pajak.

\section{Teori Atribusi}

Dalam teori atribusi dijelaskan bahwa perilaku seseorang dalam hal ini karakter, sikap dan lainnya dipengaruhi oleh keadaan eksternal seperti tekanan situasi atau keadaan yang memaksa seseorang untuk melakukan tindakan tertentu. Menurut Santrock (2003), yang dikutip dari yanah (2013), teori atribusi adalah pandangan orang seperti termotivasi untuk menemukan ke penyebab perilaku sebagai bagian dari upaya mereka untuk memahami perilaku.

\section{Teori Of Planned behaviour (TPB)}


Theory of Planned Behavior (Ajzen, 1991) yang dikutip dari Putri (2013) merupakan pengembangan dari Theory of Reasoned Action yang bertujuan untuk memperlihatkan hubungan dari perilaku-perilaku yang dimunculkan oleh individu untuk menanggapi sesuatu. Dalam TPB ditambahkan satu variabel yaitu kontrol keperilakuan yang dipersepsikan yang belum dijelaskan dalam TRA. Adanya variabel kontrol keperilakuan yang dipersepsikan berarti bahwa tidak semua tindakan yang diambil oleh individu berada di bawah kendali individu tersebut.

\section{Kesadaran Wajib Pajak}

Kesadaran pajak adalah suatu sikap terhadap fungsi pajak berupa konstalasi komponen kognitif, afektif, dan konatif, yang berinteraksi dalam memahami, merasakan, dan berperilaku terhadap makna dan fungsi pajak. Kesadaran perpajakan berkonsekuensi logis untuk wajib pajak, yaitu kerelaan wajib pajak memberikan kontribusi dana untuk pelaksanaan fungsi perpajakan, dengan cara membayar kewajiban perpajakannya secara tepat waktu dan tepat jumlah (Utomo, 2011).

\section{Motivasi Wajib Pajak}

Masalah inti motivasi yang berkaitan dengan perpajakan adalah bagaimana merangsang sekelompok orang yang masing-masing memiliki kebutuhan mereka yang khas untuk bekerja sama menuju pencapaian sasaran pembangunan ekonomi disuatu negara. (winardi, 2002:29).

\section{Tingkat Ekonomi}

Kartono (2006) yang dikutip dari Putri (2013), menyatakan bahwa status ekonomi adalah kedudukan seseorang atau keluarga di masyarakat berdasarkan pendapatan per bulan. Status ekonomi seseorang dapat dilihat dari pendapatan yang disesuaikan dengan harga barang pokok. Apabila seseorang atau keluarga dapat memenuhi semua kebutuhan pokok, sekunder, maupun tersiernya secara mandiri, maka dapat dikatakan bahwa individu tersebut mempunyai kondisi ekonomi yang sangat baik.

\section{Sikap Wajib Pajak atas Sanksi Denda}

Pengertian Sanksi Berupa Denda menurut Devano dan Rahayu (2006:198) "Denda adalah sanksi adminitrasi yang dikenakan terhadap pelanggaran yang berkaitan dengan kewajiban pelaporan. Sedangkan Sanksi Berupa Denda menurut Soemarso (2007:147) Sanksi Denda juga dapat muncul oleh karena tindakan Wajib Pajak sendiri atau dimunculkan oleh pihak pajak. Sanksi Denda pada umumnya, disebabkan oleh kesalahan atau tidak dipenuhinya kewajiban perpajakan tertentu.

Sanksi perpajakan merupakan jaminan bahwa ketentuan peraturan perundang-undangan perpajakan (norma Perpajakan) akan dituruti, ditaati, di patuhi. Atau bisa dengan kata lain sanksi perpajakan merupakan alat pencegah (preventif) agar wajib pajak tidak melanggar norma perpajakan. (Mardiasmo, 2008:57).

WP akan mematuhi pembayaran pajak bila memandang sanksi denda akan lebih banyak merugikannya. Semakin banyak sisa tunggakan pajak yang harus dibayar WP, maka akan semakin berat bagi WP untuk melunasinya.

\section{Kepatuhan Wajib Pajak}

Menurut Simon James et al (2008) yang di kutip dari Yanah (2013), kepatuhan pajak (tax compliance) adalah seorang wajib pajak memiliki kemauan untuk memenuhi kewajiban pajaknya sesuai dengan aturan yang berlaku tanpa perlu diadakannya pemeriksaan, penyelidikan menyeluruh, peringatan atau ancaman dan penerapan sanksi baik hukum atau administratif. Dan menurut Santoso (2008) yang dikutip dari Yanah (2013), kepatuhan pajak adalah suatu keadaan dimana wajib pajak memenuhi semua kewajiban pajak dan menggunakan hak perpajakan.

\section{Pajak}

Pajak menurut Soemitro dalam Mardiasmo (2008:1), adalah iuran rakyat kepada kas negara berdasarkan undang-undang (yang dapat dipaksakan) dengan tiada mendapat jasa timbal (kontraprestasi) yang langsung dapat ditunjukan dan yang digunakan untuk membayar pengeluaran Umum.

\section{Pajak Bumi dan Bangunan Pedesaan dan Perkotaan (PBB P2)}

Menurut undang-undang nomor 28 tahun 2009 tentang Pajak Daerah dan Retribusi Daerah, Pajak Bumi dan Bangunan (PBB) Pedesaan dan Perkotaan adalah pajak atas bumi dan/atau bangunan yang dimiliki, dikuasai, dan/atau dimanfaatkan oleh orang pribadi atau badan, kecuali kawasan yang digunakan untuk kegiatan usaha perkebunan, perhutanan, dan pertambangan. Bumi adalah permukaan bumi yang meliputi tanah dan perairan pedalaman serta laut wilayah kabupaten/kota. Sedangkan bangunan adalah konstruksi teknik yang ditanam atau dilekatkan secara tetap pada tanah dan/atau perairan pedalaman dan/atau laut. 


\section{KERANGKA KONSEPTUAL}

\section{Kerangka konseptual Penelitian}

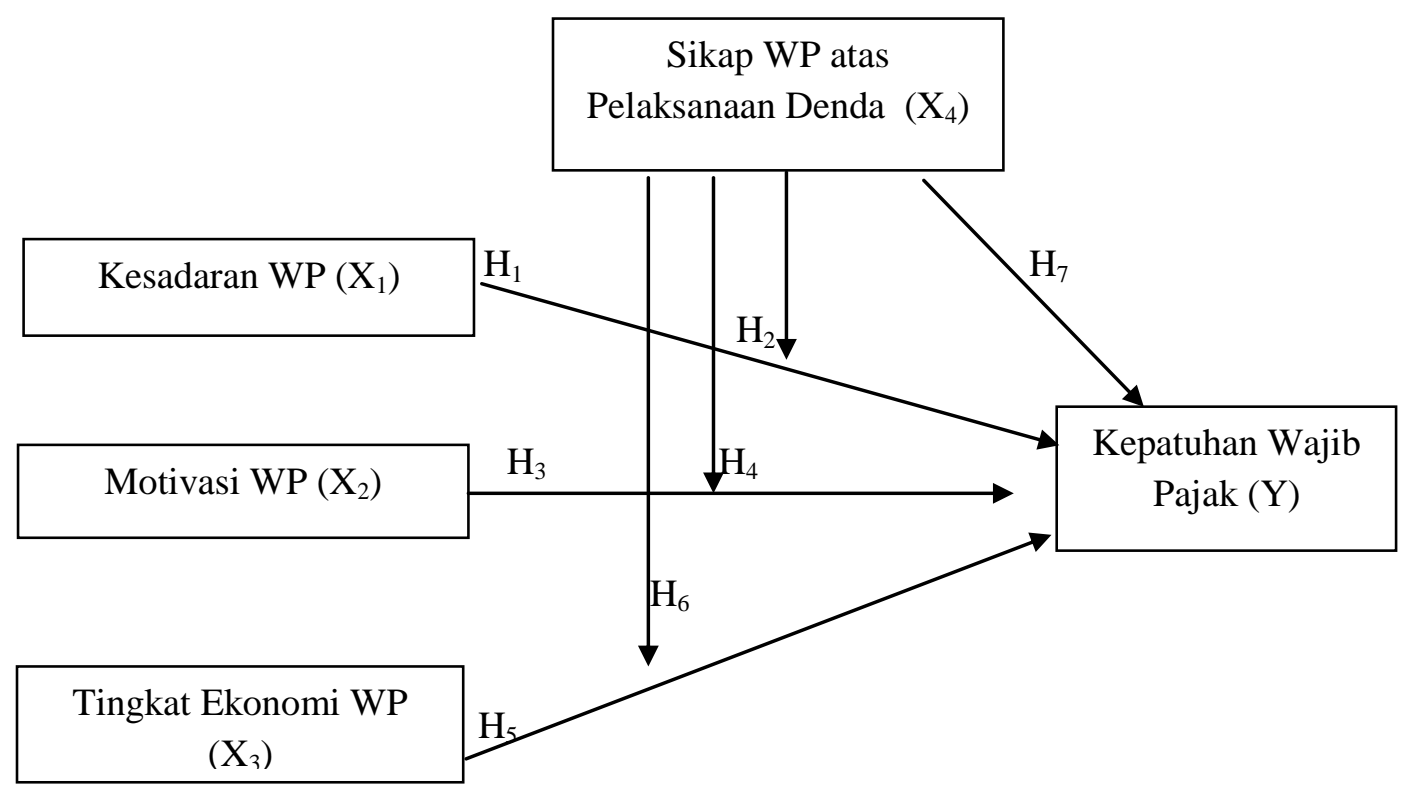

Gambar 3.1 Kerangka Konseptual Penelitian

\section{Hipotesis Penelitian}

1. Pengaruh kesadaran wajib pajak terhadap kepatuhan wajib pajak

Suryadi (2006) yang dikutip dari Ibtida (2010), menyatakan kesadaran Wajib Pajak dengan empat dimensi, yaitu: persepsi Wajib Pajak, pengetahuan perpajakan, karakteristik Wajib Pajak dan penyuluhan perpajakan. Wajib Pajak dikatakan sadar untuk membayar pajak ketika ia memiliki persepsi yang positif terhadap pajak, memiliki pengetahuan yang cukup tentang perpajakan, memiliki karakteristik yang patuh dan telah mendapatkan penyuluhan yang memadai. Berdasarkan pada beberapa argumentasi diatas maka peneliti menetapkan hipotesis pertama penelitian sebagai berikut :

\section{$H_{1}$ : Kesadaran wajib pajak berpengaruh signifikan terhadap kepatuhan wajib Pajak.}

2. Sikap wajib pajak atas sanksi denda memperkuat pengaruh kesadaran wajib pajak terhadap kepatuhan wajib pajak

Adanya faktor dari luar wajib pajak seperti Sanksi denda atas pembayaran PBB juga dapat memperkuat atau memperlemah hubungan kesadaran wajib pajak terhadap kepatuhan pajak. Pengaruh yang diberikan tersebut terjadi apabila terdapat sanksi denda yang merugikannya. Dimana Semakin banyak sisa tunggakan pajak yang harus dibayar wajib pajak, maka akan semakin berat bagi wajib pajak untuk melunasinya. Oleh sebab itu sanksi denda diduga akan berpengaruh terhadap tingkat kepatuhan wajib pajak dalam membayar pajak. Berdasarkan pada beberapa argumentasi diatas maka peneliti menetapkan hipotesis kedua penelitian sebagai berikut :

$\mathrm{H}_{2}$ : sikap wajib pajak atas sanksi denda memperkuat pengaruh kesadaran wajib pajak terhadap kepatuhan Wajib Pajak.

\section{Pengaruh motivasi wajib pajak terhadap kepatuhan wajib pajak}

Masalah inti motivasi yang berkaitan dengan perpajakan adalah bagaimana merangsang sekelompok orang yang masing-masing memiliki kebutuhan mereka yang khas untuk bekerja sama menuju pencapaian sasaran pembangunan ekonomi disuatu negara. Penelitian yang dilakukan oleh Dianawati (2008) tentang analisis pengaruh motivasi dan tingkat pendidikan terhadap kepatuhan wajib pajak. Hasil peneltiannya menunjukan bahwa motivasi berpengaruh signifikan terhadap kepatuhan wajib pajakBerdasarkan pada beberapa argumentasi diatas maka peneliti menetapkan hipotesis ketiga penelitian sebagai berikut :

\section{$\mathrm{H}_{3}$ : Motivasi wajib pajak berpengaruh signifikan terhadap kepatuhan wajib pajak.}


4. Sikap wajib pajak atas sanksi denda memperkuat pengaruh motivasi wajib pajak terhadap kepatuhan wajib pajak.

Beberapa bukti empiris seperti penelitian Bambang Suhardito (1996), Fraternesi (2001) dan Sulud Kahono (2003) yang dikutip dari Jatmiko (2006), telah menunjukkan bahwa sikap wajib pajak terhadap sanksi berpengaruh positif terhadap kepatuhan wajib pajak.

Semakin tinggi sanksi denda yang diberikan akan menambah pengeluaran wajib pajak, maka pengaruh motivasi terhadap kepatuhan wajib pajak dalam membayar PBB yang telah dibentuk semakin memperlihatkan kecenderungan niat (attention) yang semakin kuat. Hal tersebut terjadi karena adanya pengaruh dari dalam diri wajib pajak yang diperkuat dengan pengaruh dari luar wajib pajak. Niat tersebut kemudian memunculkan perilaku (Behavior) patuh terhadap pajak. Berdasarkan pada beberapa argumentasi diatas maka peneliti menetapkan hipotesis keempat penelitian sebagai berikut :

$\mathrm{H}_{4}$ : Sikap wajib pajak atas pelaksanaan sanksi denda memperkuat pengaruh motivasi wajib pajak terhadap kepatuhan wajib pajak.

\section{Pengaruh tingkat ekonomi wajib pajak terhadap kepatuhan wajib pajak}

Menurut Putri \& Isgiyarta (2013), kontribusi masyarakat bagi perkembangan dan pertumbuhan ekonomi di Indonesia salah satunya dengan memberikan kontribusi berupa pembayaran pajak kepada negara. Wajib pajak dapat melakukan pembayaran pajak tersebut pastinya dengan menyisihkan sebagian pendapatan yang diperolehnya. Apabila wajib pajak mempunyai pendapatan yang cukup, maka individu tersebut mampu untuk memenuhi kebutuhan hidup dan kewajibannya sebagai warga negara yang baik yaitu dengan membayar pajak tepat pada waktunya. Berdasarkan pada argumentasi ditersebut maka peneliti menetapkan hipotesis kelima penelitian sebagai berikut :

$\mathrm{H}_{5}$ : Tingkat ekonomi wajib pajak berpengaruh signifikan terhadap kepatuhan wajib pajak.

6. Sikap wajib pajak atas sanksi denda memperkuat pengaruh

Beberapa bukti empiris seperti penelitian Suhardito (1996), Fraternesi (2001) dan Kahono (2003) yang dikutip dari Jatmiko (2006), telah menunjukkan bahwa sikap wajib pajak terhadap sanksi berpengaruh positif terhadap kepatuhan wajib pajak. Semakin tinggi pelaksanaan sanksi denda yang diberikan akan menambah pengeluaran wajib pajak, maka pengaruh tingkat ekonomi terhadap kepatuhan wajib pajak dalam membayar PBB yang telah dibentuk semakin memperlihatkan kecenderungan niat (attention) yang semakin kuat. Hal tersebut dikarena ada pengaruh dari dalam diri wajib pajak yang diperkuat dengan pengaruh dari luar wajib pajak. Niat tersebut kemudian memunculkan perilaku (Behavior) patuh terhadap pajak. Berdasarkan pada beberapa argumentasi diatas maka peneliti menetapkan hipotesis keenam penelitian sebagai berikut :

$\mathrm{H}_{6}$ : Sikap wajib pajak atas sanksi denda memperkuat pengaruh tingkat ekonomi wajib pajak terhadap kepatuhan wajib pajak.

7. Pengaruh sikap wajib pajak atas sanksi denda terhadap kepatuhan wajib pajak

Sanksi perpajakan merupakan jaminan bahwa ketentuan peraturan perundang-undangan perpajakan (norma perpajakan) akan dituruti, ditaati, di patuhi, dengan kata lain sanksi perpajakan merupakan alat pencegah agar wajib pajak tidak melanggar norma perpajakan (Mardiasmo, 2008:57). Wajib pajak akan mematuhi pembayaran pajak bila memandang sanksi denda akan lebih banyak merugikannya. Semakin banyak sisa tunggakan pajak yang harus dibayar Wajib pajak, maka akan semakin berat bagi wajib pajak untuk melunasinya.

Penelitian yang dilakukan oleh Jatimiko (2006) tentang pengaruh sikap wajib Pajak terhadap pelaksanaan sanksi denda, pelayanan fiskus dan kesadaran wajib pajak terhadap kepatuhan wajib pajak menunjukan bahwa sikap WP terhadap pelaksanaan sanksi denda secara parsial memiliki pengaruh positif yang signifikan terhadap kepatuhan WP. Hal ini menunjukkan bahwa makin tinggi sikap WP terhadap pelaksanaan sanksi denda maka makin tinggi pula kepatuhan WP.Berdasarkan pada beberapa argumentasi diatas maka peneliti menetapkan hipotesis ketujuh penelitian sebagai berikut :

$H_{7}$ : Sikap wajib pajak atas pelaksanaan sanksi denda berpengaruh signifikan terhadap kepatuhan wajib pajak.

\section{METODE PENELITIAN}

\section{Jenis dan Rancangan Penelitian}

Penelitian ini merupakan jenis penelitian kuantitatif dengan menggunakan pendekatan korelasional dengan menggunakan variabel moderating. yaitu penelitian atau penelaahan hubungan antara variabel bebas dengan 
variabel tergantung tetapi juga muncul adanya variabel yang ikut mempengaruhi hubungan antara variabel tersebut yaitu variabel moderasi (Jatmiko, 2006). Dimana dalam penelitian ini yaitu untuk menguji hubungan/pengaruh antara kesadaran wajib pajak, Motivasi wajib pajak, dan tingkat ekonomi wajib pajak terhadap kepatuhan wajib pajak yang dimoderasi oleh pelaksanaan sanksi denda.

\section{Populasi dan Sampel}

Populasi adalah kumpulan individu yang memiliki kualitas-kualitas dan ciri-ciri yang telah ditetapkan. Berdasarkan kualitas dan ciri tersebut, populasi dapat dipahami sebagai sekelompok individu atau obyek pengamatan yang minimal memiliki satu persamaan karakteristik. (Jatmiko, 2006). Populasi dalam penelitian ini adalah wajib Pajak Bumi dan bangunan di Kota Tidore Kepulauan.

Pengambilan sampel pada penelitian ini adalah dengan menggunakan metode Propotional Sampling. Hair et al. (1998) dikutip dari Jatmiko (2006) menyatakan bahwa jumlah sampel minimal yang harus diambil apabila menggunakan teknik analisis regresi berganda adalah 15 hingga 20 kali jumlah variabel yang digunakan. Jumlah variabel yang digunakan dalam penelitian ini adalah 4 variabel sehingga jumlah sampel minimal yang harus diambil adalah 4 × $20=80$.

Penentuan jumlah sampel ditentukan dengan mengunakan rumus berikut (Rao, 1996) yang dikutip dari Jatmiko (2006) :

$\mathrm{n}=$ jumlah sampel

$\mathrm{N}=$ populasi

Moe = margin of error max yaitu tingkat kesalahan maksimum yang masih dapat ditoleransi (ditentukan 10\%).

Dimana :

$\mathrm{n}=99,99$

$\mathrm{n}=100$

\section{Klasifikasi Variabel dan Defenisi Variabel Operasional}

1. Kesadaran Wajib Pajak $\left(\mathbf{X}_{1}\right)$

Kesadaran adalah keadaan mengetahui atau mengerti, sedangkan perpajakan adalah perihal pajak, sehingga kesadaran perpajakan adalah keadaan mengetahui atau mengerti perihal pajak (Agustina, 2006) (dikutip dari Putri, 2013).

2. Motivasi Wajib Pajak $\left(X_{2}\right)$

Masalah inti motivasi yang berkaitan dengan perpajakan adalah bagaimana merangsang sekelompok orang yang masing-masing memiliki kebutuhan mereka yang khas untuk bekerja sama menuju pencapaian sasaran pembangunan ekonomi disuatu negara.

3. Tingkat Ekonomi Wajib Pajak $\left(\mathbf{X}_{3}\right)$

Menurut Kartono (2006) dikutip dari Putri (2013), status ekonomi adalah kedudukan seseorang atau keluarga di masyarakat berdasarkan pendapatan per bulan. Status ekonomi seseorang dapat dilihat dari pendapatan yang disesuaikan dengan harga barang pokok. Apabila seseorang atau keluarga dapat memenuhi semua kebutuhan pokok, sekunder, maupun tersiernya secara mandiri, maka dapat dikatakan bahwa individu tersebut mempunyai kondisi ekonomi yang sangat baik.

4. Sikap Wajib atas Pelaksanaan Sanksi Denda $\left(\mathbf{X}_{4}\right)$ Sebagai Variabel Moderator.

Sikap WP terhadap pelaksanaan sanksi denda yaitu sikap responden tentang pelaksanaan sanksi denda terhadap responden dan orang lain di sekitar responden (Suyatmin, 2004).

\section{Kepatuhan Wajib Pajak (Y)}

Menurut Eliyani (1989) yang di kutip dari Jatmiko (2006), menyatakan bahwa kepatuhan wajib pajak didefinisikan sebagai memasukkan dan melaporkan kepada waktunya informasi yang diperlukan, mengisi secara benar jumlah pajak yang terutang, dan membayar pajak pada waktunya tanpa tindakan pemaksaan.

\section{ANALISIS DAN PEMBAHASAN HASIL PENELITIAN Uji Reliabiltas}

Uji reliabiltas merupakan salah satu alat untuk mengukur suatu kuesioner yang merupakan indikator dari variabel atau konsrtuk (Ghozali, 2006:45). Menurut Nunnanlly dalam Ghozali (2006:46) suatu konstruk atau variabel dikatakan reliabel jika memberikan nilai Cronbach's Alpha $>60$. 
Hasil uji reliabilitas terhadap pertanyaan kuesioner variabel-variabel penelitian antara lain, variabel kesadaran wajib pajak $\left(\mathrm{X}_{1}\right)$ memiliki nilai Cronbach's Alpha sebesar 0,73 lebih besar dari 0,60, variabel motivasi wajib pajak $\left(\mathrm{X}_{2}\right)$ memiliki nilai Cronbach's Alpha sebesar 0,63 lebih besar dari 0,60, variabel tingkat ekonomi wajib pajak $\left(\mathrm{X}_{3}\right)$ memiliki nilai Cronbach's Alpha sebesar 0,62 yang lebih besar dari 0,060, variabel sikap wajib pajak atas sanksi denda $\left(\mathrm{X}_{4}\right)$ memiliki nilai Cronbach's Alpha sebesar 0,88 lebih besar dari 0,60, dan variabel kapatuhan wajib pajak (Y) memiliki nilai Cronbach's Alpha sebesar 0,68 lebih besar dari 0,60. Dari hasil pengujian tersebut dapat disimpulkan bahwa semua pertanyaan dalam kuesioner dari semua variabel penelitian adalah reliabel atau handal.

\section{Uji Validitas}

Uji Validitas digunakan untuk mengukur sah atau tidaknya suatu kuesioner. Suatu kuesioner dikatakan valid jika pertanyaan pada kuesioner mampu untuk mengungkapkan sesuatu yang akan diukur oleh kuesioner tersebut (Ghozali, 2006:50). Dalam penelitian ini peneliti menggunakan uji validitas dengan cara melakukan korelasi bivariat antara masing-masing skor indikator dengan total skor konstruk atau variabel.

Hasil uji validitas dalam penelitian ini antara lain, untuk pertanyaan kuesioner variabel kesadaran wajib pajak $\left(\mathrm{X}_{1.1}-\mathrm{X}_{1.4}\right)$ memiliki nilai masing-masing sebesar 0,223, 0,910, 0,930, dan 0,687 yang lebih besar dari tingkat signifikansi statistik sebesar 0,05 , pertanyaan kuesioner variabel motivasi wajib pajak $\left(\mathrm{X}_{2.1}-\mathrm{X}_{2.4}\right)$ memiliki nilai masing-masing sebesar 0,545, 0,683, 0,791, dan 0,729 yang lebih besar dari tingkat signifikansi statistik sebesar 0,05 , pertanyaan kuesioner variabel tingkat ekonomi wajib pajak $\left(\mathrm{X}_{3.1}-\mathrm{X}_{3.4}\right)$ memiliki nilai masing-masing sebesar $0,659,0,747,0,666$, dan 0,658 yang lebih besar dari tingkat signifikansi statistik sebesar 0,05 , pertanyaan kuesioner variabel sikap wajib pajak atas sanksi denda $\left(\mathrm{X}_{4.1}-\mathrm{X}_{4.4}\right)$ memiliki nlai masing-masing sebesar 0,924, 0,763, 0,896, dan 0,849 yang lebih besar dari tingkat signifikansi statistik sebesar 0,05, dan pertanyaan kuesioner variabel kepatuhan wajib pajak $\left(\mathrm{Y}_{1.1}-\mathrm{Y}_{1.4}\right)$ memiliki nilai masing-masing sebesar $0,717,0,785,0,887$, dan 0,390 yang lebih besar dari tingkat signifikansi statitik sebesar 0,05. Dari hasil pengujian tersebut dapat disimpulkan bahwa pertanyaan kuesioner dari variabel-variabel dalam penelitian ini adalah valid.

\section{Uji Normalitas}

Hasil uji normalitas dalam penelitian ini diuji dengan menggunakan uji kolmogorov smirnov yang memiliki nilai sebesar 0,10, lebih dari tingkat signifikansi statistik sebesar 0,05 , hal tersebut menunjukan bahwa data dalam penelitian ini terdistribusi normal, Sehingga dapat disimpulkan bahwa data dalam penelitian ini lolos uji asumsi klasik yakni uji normalitas.

\section{Uji Autokorelasi}

Hasil uji autokorelasi dalam penelitian ini dilakukan dengan cara melihat angka durbin watson. Dari hasil penelitian menunjukan bahwa angka durbit watson adalah sebesar 1,751 yang berada diantara -2 sampai 2 sehingga dapat disimpulkan bahwa antar data penelitian tidak terjadi autokorelasi. Hal ini menunjukan bahwa data dalam penelitian ini lolos uji asumsi klasik yakni uji autokorelasi.

\section{Uji Heterokedastisitas}

Hasil uji heterokedastisitas dalam penelitian ini di uji dengan menggunakan uji park. Hasil uji park terhadap variabel-variabel independen penelitian memiliki nilai masing-masing sebesar $0,582,0,583,0,627$, dan 0,212 , yang lebih besar dari tingkat signifikansi statistik sebesar 0,05 . Hal tersebut menunjukan bahwa varians penelitian tidak mengalami efek heterokedastisitas atau varians data adalah homokedastisitas. Hal tersebut dapat simpulkan bahwa data dalam penelitian ini lolos uji asumsi klasik, yakni uji heterokedastisitas.

\section{Uji Multikolonearitas}

Hasil uji multikolonearitas dalam penelitian ini diuji dengan melihat nilai VIF setiap variabel independen yakni $\mathrm{X}_{1}-\mathrm{X}_{3} \mathrm{X}_{4}$ masing-masing antara lain 1,027, 1,193, 1,263, 2,802, 1,403, 2,791 adalah berada dibawah 10, maka dapat disimpulkan bahwa antar variabel independen tidak terjadi efek multikolonearitas. Hal ini menunjukan bahwa data dalam penelitian ini lolos uji asumsi klasik, yaitu uji multikolonearitas.

\section{Koefisien Determinasi}

Hasil uji koefisien determinasi menunjukan bahwa nilai adjusted $\mathrm{R}$ square $\left(\mathrm{R}^{2}\right)$ variabel kesadaran wajib pajak $\left(\mathrm{X}_{1}\right)$, motivasi wajib pajak $\left(\mathrm{X}_{2}\right)$, tingkat ekonomi wajib pajak $\left(\mathrm{X}_{3}\right)$, sikap wajib pajak atas sanksi denda $\left(\mathrm{X}_{4}\right)$ adalah sebesar 0,564 atau 56,4\%. Hal ini menunjukan bahwa 56,8\% variasi kepatuhan wajib pajak dapat dijelaskan oleh variasi keempat variabel independen yaitu kesadaran wajib pajak, motivasi wajib pajak, tingkat ekonomi wajib pajak, dan sikap wajib pajak atas sanksi denda. Sementara sisanya $(100 \%-56,4 \%=43,6 \%) 43,6 \%$ dijelaskan oleh variabel lain diluar model.

\section{Uji statistik t (Uji t)}

1. Pengaruh kesadaran wajib pajak terhadap kepatuhan wajib pajak

Hasil uji statistik $\mathrm{t}$ dengan menggunakan regresi berganda dalam menjawab hipotesis pertama penelitian, memperlihatkan bahwa tingkat signifikansi variabel kesadaran wajib pajak $\left(\mathrm{X}_{1}\right)$ adalah sebesar 0,906 lebih besar dari tingkat signifikansi statistik sebesar 0,05, yang menunjukan bahwa kesadaran wajib 
pajak tidak berpengaruh signifikan terhadap kepatuhan wajib pajak dalam membayar PBB. Hal tersebut dipengaruhi oleh adanya persepsi masyarakat yang kurang positif terhadap kinerja pemerintah daerah, dalam hal ini dinas pendapatan daerah kota tidore kepulauan yang dianggapkan kurang baik dalam mengelola PBB.

Berdasarkan pada hasil penelitian tersebut maka hasil penelitian ini berbeda dengan hasil penelitian sebelumnya yang dilakukan oleh Jatmiko (2006) dan Utomo (2011) yang menunjukan bahwa kesadaran wajib pajak berpengaruh terhadap kepatuhan wajib pajak. dimana semakin tinggi sikap wajib pajak terhadap kesadaran perpajakan maka makin tinggi pula kepatuhan.

2. Pengaruh kesadaran wajib pajak terhadap kepatuhan wajib pajak yang dimoderasi oleh sikap wajib pajak atas sanksi denda.

Hasil uji statistik dengan metode uji nilai selisih mutlak menggunakan regresi berganda dalam menjawab hipotesis penelitian kedua, mempelihatkan bahwa tingkat signifikansi variabel $\mathrm{X}_{1} \mathrm{X}_{4}$ yang dipersepsikan sebagai variabel moderating adalah sebesar 0,249 yang lebih dari tingkat signifikansi statistik sebesar 0,05 , yang berarti bahwa variabel $\mathrm{X}_{1} \mathrm{X}_{4}$ bukan merupakan variabel moderating. Sementara variabel kesadaran wajib pajak $\left(\mathrm{X}_{1}\right)$ sebesar 0,906 dan variabel sikap wajib pajak atas sanksi denda $\left(\mathrm{X}_{4}\right)$ sebesar 0,000 , hal ini berarti bahwa variabel $X_{1}$ lebih besar dan variabel $X_{2}$ lebih kecil dari tingat signifikansi statistik yakni sebesar 0,05 . Dengan demikian dapat disimpulkan bahwa sikap wajib pajak atas sanksi denda tidak dapat memperkuat pengaruh kesadaran wajib pajak terhadap kepatuhan wajib pajak, karena variabel tersebut bukan merupakan variabel moderating melainkan variabel independen.

3. Pengaruh motivasi wajib pajak terhadap kepatuhan wajib pajak.

Hasil uji statistik $\mathrm{t}$ dengan menggunakan regresi berganda dalam menjawab hipotesis ketiga, memperlihatkan bahwa tingkat signifikansi variabel motivasi wajib pajak $\left(\mathrm{X}_{2}\right)$ adalah sebesar 0,229 lebih besar dari tingkat signifikansi statistik sebesar 0,05 , yang berarti bahwa motivasi wajib pajak tidak berpengaruh terhadap kepatuhan wajib pajak. hal tersebut menunjukan bahwa pemerintah daerah kota tidore kepulauan melalui dinas pendapatan daerah kota tidore kepulauan kurang serius dan transpran dalam mengelola PBB sehingga memberikan hasil yang kurang terhadap pembangunan di kota tidore kepulauan, akibatnya mempengaruhi motivasi wajib pajak dalam membayar PBB.

Dengan demikian maka hasil penelitian ini berbeda dengan penelitian sebelumnya yang dilakukan oleh Dianawati (2008) yang menunjukan bahwa motivasi wajib pajak berpengaruh positif signifikan terhada kepatuhan wajib pajak. Dimana motivasi wajib pajak yang positif dapat ditunjukan dengan adanya faktor kebutuhan yang cukup berarti, dan adanya kesadaran akan perlunya membayar pajak.

4. Pengaruh motivasi wajib pajak terhadap kepatuhan wajib pajak yang dimoderasi oleh sikap wajib pajak atas sanksi denda.

Hasil uji statistik dengan metode uji nilai selisih mutlak menggunakan regresi berganda dalam menjawab hipotesis penelitian keempat, mempelihatkan bahwa tingkat signifikansi variabel $\mathrm{X}_{2} \mathrm{X}_{4}$ yang dipersepsikan sebagai variabel moderating adalah sebesar 0,596 yang lebih dari tingkat signifikansi statistik sebesar 0,05 , yang berarti bahwa variabel $\mathrm{X}_{2} \mathrm{X}_{4}$ bukan merupakan variabel moderating. Sementara variabel motivasi wajib pajak $\left(\mathrm{X}_{2}\right)$ sebesar 0,229 dan variabel sikap wajib pajak atas sanksi denda $\left(\mathrm{X}_{4}\right)$ sebesar 0,000 , hal ini berarti bahwa variabel $X_{1}$ lebih besar dan variabel $X_{2}$ lebih kecil dari tingat signifikansi statistik yakni sebesar 0,05 . Dengan demikian dapat disimpulkan bahwa sikap wajib pajak atas sanksi denda tidak dapat memperkuat pengaruh motivasi wajib pajak terhadap kepatuhan wajib pajak, karena variabel tersebut bukan merupakan variabel moderating melainkan variabel independen.

5. Pengaruh tingakat ekonomi wajib pajak terhadap kepatuhan wajib pajak

Hasil uji statistik $\mathrm{t}$ dengan menggunakan regresi berganda dalam menjawab hipotesis kelima, memperlihatkan bahwa tingkat signifikansi variabel tingkat ekonomi wajib pajak $\left(\mathrm{X}_{3}\right)$ adalah sebesar 0,296 lebih besar dari tingkat signifikansi statistik sebesar 0,05, yang menunjukan bahwa tingkat ekonomi wajib pajak tidak berpengaruh terhadap kepatuhan wajib pajak. hal tersebut menunjukan bahwa besaran tarif PBB yang dibayar oleh wajib pajak tidak mempengaruhi tingkat ekonomi wajib pajak dalam hal ini yaitu berupa pendapatan dan pengeluaran wajib pajak perbulan.

Dengan demikian maka penelitian ini berbeda dengan penelitian sebelumnya yang dilakukan oleh Putri (2013), yang menunjukan bahwa tingkat ekonomi wajib pajak berpengaruh negatif terhadap kepatuhan wajib pajak dalam membayar PBB. Dimana keadaan ekonomi yang dimiliki oleh wajib pajak dapat menjadi suatu dorongan motivasi untuk dapat memenuhi kewajiban PBB yang dimiliki.

6. Pengaruh tingkat ekonomi wajib pajak terhadap kepatuhan wajib pajak yang dimoderasi oleh sikap wajib pajak atas sanksi denda.

Hasil uji statistik dengan metode uji nilai selisih mutlak menggunakan regresi berganda dalam menjawab hipotesis penelitian keenam, mempelihatkan bahwa tingkat signifikansi variabel $\mathrm{X}_{3} \mathrm{X}_{4}$ yang 
dipersepsikan sebagai variabel moderating adalah sebesar 0,533 yang lebih dari tingkat signifikansi statistik sebesar 0,05 , yang berarti bahwa variabel $\mathrm{X}_{2} \mathrm{X}_{4}$ bukan merupakan variabel moderating. Sementara variabel tingkat ekonomi wajib pajak $\left(\mathrm{X}_{3}\right)$ sebesar 0,296 dan variabel sikap wajib pajak atas sanksi denda $\left(\mathrm{X}_{4}\right)$ sebesar 0,000 , hal ini berarti bahwa variabel $X_{1}$ lebih besar dan variabel $X_{2}$ lebih kecil dari tingat signifikansi statistik yakni sebesar 0,05. Dengan demikian dapat disimpulkan bahwa sikap wajib pajak atas sanksi denda tidak dapat memperkuat pengaruh tingkat ekonomi wajib pajak terhadap kepatuhan wajib pajak, karena variabel tersebut bukan merupakan variabel moderating melainkan variabel independen.

\section{Pengaruh sikap wajib pajak atas sanksi denda terhadap kepatuhan wajib pajak}

Hasil uji statistik $\mathrm{t}$ dengan menggunakan regresi berganda dalam menjawab hipotesis ketujuh, memperlihatkan bahwa tingkat signifikansi variabel sikap wajib pajak atas sanksi denda $\left(\mathrm{X}_{4}\right)$ adalah sebesar 0,000 lebih besar dari tingkat signifikansi statistik sebesar 0,05, yang menunjukan bahwa sikap wajib pajak atas sanksi denda berpengaruh terhadap kepatuhan wajib pajak. hal tersebut menunjukan bahwa wajib pajak memadang sanksi denda akan lebih merugikannya, dimana semakin banyak sisa tunggakan pajak yang harus dibayar wajib pajak maka akan semakin berat bagi wajib pajak untuk melunasinya sehingga mempengaruhi kepatuhan mereka dalam membayaran PBB.

Dengan demikian maka hal penelitian ini mendukung penelitian sebelumnya yang dilakukan oleh Jatmiko (2006) yang menunjukan bahwa sikap wajib pajak atas sanksi denda berpengaruh terhadap kepatuhan wajib pajak dalam membayar PBB.

\section{SIMPULAN DAN SARAN}

\section{Simpulan}

1. Kesadaran Wajib Pajak secara parsial tidak berpengaruh terhadap kepatuhan wajib pajak dalam membayar PBB. Hal tersebut menunjukan bahwa persepsi masyarakat kurang positif terhadap kinerja pemerintah daerah, dalam hal ini dinas pendapatan dan aset daerah kota tidore kepulauan yang kurang baik dalam mengelola Pajak bumi dan bangunan (PBB), sehingga mengurangi minat masyarakat dalam membayar PBB.

2. Kesadaran Wajib Pajak tidak berpengaruh terhadap Kepatuhan Wajib dalam membayar PBB yang dimoderasi oleh Sikap Wajib Pajak atas sanksi denda. Hal tersebut menunjukan bahwa Sikap Wajib Pajak atas sanksi denda bukan merupakan variabel moderating melainkan merupakan variabel independen.

3. Motivasi Wajib Pajak tidak berpengaruh terhadap Kepatuhan Wajib Pajak dalam membayar PBB. Hal tersebut menunjukan bahwa Pemerintah Daerah Kota Tidore Kepulauan kurang serius dan transparan dalam mengelola Pajak Bumi dan Bangunan (PBB) sehingga memberikan yang hasil kurang maksimal terhadap pembangunan di Kota Tidore Kepulauan, akibatnya mempengaruhi motivasi wajib pajak dalam membayar PBB.

4. Motivasi Wajib Pajak tidak berpengaruh terhadap Kepatuhan Wajib Pajak dalam membayar PBB yang dimoderasi oleh Sikap Wajib Pajak atas Sanksi Denda. Hal tersebut menunjukan bahwa Sikap Wajib Pajak atas Pelaksanaan Sanksi Denda bukan merupakan variabel moderating melainkan merupakan variabel independen.

5. Tingkat ekonomi Wajib Pajak tidak berpengaruh terhadap Kepatuhan Wajib Pajak dalam membayar PBB. Hal tersebut menunjukan bahwa besaran tarif PBB yang dibayar oleh Wajib Pajak tidak mempengaruhi tingkat ekonomi wajib pajak, yaitu berupa besaran pendapatan dan pengeluaran Wajib Pajak perbulan.

6. Tingkat Ekonomi Wajib Pajak tidak berpengaruh signifikan terhadap Kepatuhan Wajib Pajak dalam membayar PBB yang dimoderasi oleh Sikap Wajib Pajak atas Pelaksanaan Sanksi Denda. Hal tersebut menunjukan bahwa Sikap Wajib Pajak atas Sanksi Denda bukan merupakan variabel moderating melainkan merupakan variabel indenpenden.

7. Sikap Wajib Pajak atas Sanksi Denda berpengaruh signifikan terhadap Kepatuhan Wajib Pajak dalam membayar PBB. Hal tersebut menunjukan bahwa wajib pajak memadang sanksi berupa denda akan lebih merugikannya, karena semakin banyak sisa tunggakan pajak yang harus dibayar wajib pajak maka akan semakin berat bagi wajib pajak untuk melunasinya sehingga mempengaruhi kepatuhan mereka dalam membayar PBB.

\section{Saran}

1. Memberikan rekomendasi kepada Pemerintah Daerah Kota Tidore Kepulauan melalui Dinas Pendapatan Daerah Kota Tidore Kepulauan agar lebih transparan dan serius dalam mengelola Pajak bumi dan bangunan (PBB) yakni dengan cara mengalokasikan anggaran yang bersumber dari penerimaan PBB untuk pembangunan infrastruktur yang lebih produktif dan dibutuhkan oleh masyarakat.

2. Memberikan rekomendasi kepada Kepala Dinas Pendapatan Daerah kota tidore kepulauan untuk meningkatkan mutu pelayanan terhadap penagihan PBB, dengan cara memberikan insentif dan penghargaan kepada para petugas penagihan yang berhasil mencapai target dalam melakukan penagihan PBB sehingga 
kinerja para petugas penagihan tersebut diharapkan dapat meningkat, serta memberikan penghargaan kepada wajib pajak perkelurahan yang taat dalam membayar PBB. dengan demikian maka diharapkan minat masyarakat dapat meningkat dan masyarakat dengan sendirinya sadar, termotivasi dan akan memberikan sifat patuh dalam membayar PBB.

3. Memberikan rekomendasi kepada Pemerintah Daerah Kota Tidore Kepulauan melalui Dinas Pendapatan Daerah Kota Tidore Kepulauan untuk lebih giat melakukan sosialisasi akan pentingnya PBB bagi keberlangsungan Pembangunan dikota tidore kepulauan serta menginformasikan kepada masyarakat luas bahwa hasil pembayaran PBB telah diwujudkan dalam bentuk pembangunan sejumlah Fasilitas publik yang telah dinikmati oleh Masyarkat.

4. Memberikan rekomendasi kepada Pemerintah Daerah Kota Tidore Kepulauan melalui Dinas Pendapatan Daerah Kota Tidore Kepulauan agar dalam menerbitkan surat ketetapan PBB P2, perlu untuk menganalisa dan mempertimbangkan faktor-faktor yang mempengaruhi ketidakpatuhan pajak, khususnya ketidakpatuhan pajak yang sebabkan oleh adanya penghindaran pajak secara pasif, yaitu tindakan ketidakpatuhan yang dilakukan bukan karena kesengajaan untuk menghindari pajak melainkan karena ketidakseimbangan antara objek pajak dan kemampuan ekonomi wajib pajak. Guna untuk mendukung hal tersebut maka perlu untuk ditetapkan dalam PERDA Kota Tidore Kepulauan.

\section{DAFTAR PUSTAKA}

Devano, Sony dan Rahayu, S Kurnia. 2006. Perpajakan : Konsep, Teori, dan Isu. Yogyakarta : Kencana Prenada Media Grup.

Dianawati, Susi. 2008. Analisis Pengaruh Motivasi dan Tingkat PendidikanTerhadap Kepatuhan Wajib Pajak, Studi pada KPP Pratama Jakarta Tanah Abang Satu. Skripsi.

Ghozali, Imam, 2006. Aplikasi Analisis Multivariat dengan Program SPSS. Cetakan Ke IV. Semarang : Badan Penerbit Universitas Diponegoro.

Ibtida, Reisya. 2010. Pengaruh kesadaran wajib pajak dan pelayanan fiskus terhadap kinerja penerimaan pajak dengan kepatuhan wajib pajak sebagai variabel intervening, studi pada wajib pajak di Jakarta Selatan. Skripsi.

Jatmiko, A Nugroho. 2006. Pengaruh sikap wajib pajak pada Pelaksanaan sanksi denda, pelayanan Fiskus dan kesadaran perpajakan Terhadap kepatuhan wajib pajak, studi empiris terhadap wajib pajak orang pribadi di Kota semarang, Tesis.

Mardiasmo. 2008. Perpajakan edisi Revisi 2008,.Yogyakarta : Andi. Putri, Surya. 2013, Analisis pengaruh pengetahuan Umum, tingkat ekonomi, dan Pengetahuan pajak terhadap Kepatuhan PBB masyarakat desa dan Kota dengan variabel moderating Kontrol petugas desa/kelurahan, studi kasus pada kabupaten demak. Skripsi.

Putri, Surya. \& Isgiyarta, Jaka. 2013. Analisis pengaruh pengetahuan Umum, tingkat ekonomi, dan Pengetahuan pajak terhadap Kepatuhan PBB masyarakat desa dan Kota dengan variabel moderating Kontrol petugas desa/kelurahan, studi kasus pada kabupaten demak, Diponegoro Journal of Accounting Volume 2 nomor 3, ISSN (online) 2337-3806.

Soemarso, S.R. 2007. Perpajakan Pendekatan Komperehensif. Jakarta : Salemba Empat

Utomo, Wahyu. 2011. Pengaruh Sikap, Kesadaran Wajib Pajak dan Pengetahuan Perpajakan terhadap kepatuhan Wajib Pajak Dalam Membayar Pajak Bumi dan Bangunan Dikecamatan Pamulang Kota Tanggerang Selatan. Skripsi.

Winardi. 2002. Motivasi dan Pemotivasian dalam Manajemen. Jakarta : Rajawali Press Yanah. 2013. The Impact of Administratif sanction and understanding of Income Tax Law On Corporate Taxpayer's Complience, The International Journal of Social Sciences, 30 June 2013, Vol 12 No. 1. Undang-undang Republik Indonesia No 28 tahun 2009 tentang pajak daerah dan Retribusi Daerah. Undang-Undang Republik Indonesia No. 12 tahun 2008 tentang Otonomi Daerah

Undang-Undang Republik Indonesia No. 33 Tahun 2004 tentang Hubungan Perimbangan Keuangan Antara Pemerintah Pusat dan Pemerintah Daerah.

Undang-Undang Republik Indonesia No, 28 tahun 2007 tentang ketentuan Umum dan Tata Cara Perpajakan. 